\title{
超伝導回路による超高速・低消費電力マイクロプロセッサの開発
}

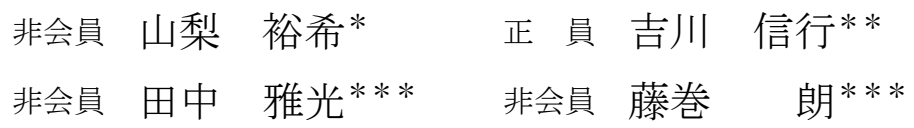

\section{Development of High-speed and Low-power Microprocessors using Superconductive Circuits} Yuki Yamanashi*, Non-member, Nobuyuki Yoshikawa**, Member, Masamitsu Tanaka***, Non-member,

Akira Fujimaki***, Non-member

Superconductive single flux quantum (SFQ) circuits, which perform their circuit operations by controlling propagations of flux quanta in connected superconducting rings, can operate at the frequency of several tens $\mathrm{GHz}$ with ultra low power dissipation. The SFQ circuit is thought to be an attractive candidate for fundamental elements of future high-end information processing systems. This paper reports the development of SFQ microprocessors for high-end computation systems.

キーワード : 単一磁束量子回路, 集積回路, ジョセフソン接合, 磁束量子, マイクロプロセッサ

Keywords : single flux quantum circuit, LSI, Josephson junction, flux quantum, microprocessor

\section{1. はじめに}

現代の情報化社会は半導体集積回路技術の発展によって 支えられてきた。半導体集積回路はその微細加工技術の発 展に支えられ，その集積度は指数関数的に上昇し続けてき た。現在では 1 つのチップに 1 億個以上のトランジスタが 集積されるまでになっている。トランジスタのゲート長は $100 \mathrm{~nm}$ を切り, ゲート絶縁膜厚は数 $\mathrm{nm}$ にも達し, 半導体 集積回路にはまさに極限のナノテクノロジーが使用されて いる。しかし, 近年半導体集積回路の発展のスピードは, リーク電流の増加による消費電力の増大や配線遅延の増大 などの要因により, 近年鈍化がみられるようになってきて いる(1)。特に集積回路のクロック周波数に関しては, その向 上に行き詰まりがはっきりと見えてきている。

この半導体集積回路の限界を打ち破る回路技術として, 超伝導単一磁束量子 (Single Flux Quantum: SFQ) 回路 ${ }^{(2)}$ があ る。SFQ 回路は超伝導回路中を伝搬する磁束量子の動きを 制御することによって回路動作を行い，超低消費電力にお

\footnotetext{
* 横浜国立大学学際プロジェクト研究センター 干240-8501 横浜市保土ケ谷区常盤台 79-5 Interdisciplinary Research Center, Yokohama National University 79-5, Tokiwadai, Hodogaya-ku, Yokohama 240-8501

** 横浜国立大学工学工学部電子情報工学科 干240-8501 横浜市保土ヶ谷区常盤台 79-5 Department of Electrical and Computer Engineering, Yokohama National University

79-5, Tokiwadai, Hodogaya-ku, Yokohama 240-8501

$* * *$ 名古屋大学工学部

干464-8603 名古屋市千種区不老町

Faculty of Engineering, Nagoya University

Furo-cho, Chikusa-ku, Nagoya 464-8603
}

いて高速動作が可能であることを特徵とする。本稿では, 我々が進めてきた，SFQ 回路を用いたマイクロプロセッサ の開発および動作実証について述べる。

\section{2. 超伝導 SFQ 回路}

超伝導リングを貫く磁束は, 超伝導体中の波動関数の一 価性により, 磁束量子 $\Phi_{0}\left(=\mathrm{h} / 2 \mathrm{e}=2.07 \times 10^{-15} \mathrm{Web}\right)$ の整数 倍に必ず量子化される。これはどのようなサイズの超伝導 リングでも起こる, 超伝導体特有の巨視的な量子効果であ る。この超伝導リング中の磁束の最小単位である磁束量子 一つ一つを情報担体として用いる超伝導単一磁束量子回路 は, 東北大の中島らによってその原型が提案され(3), 1991 年に Likharev らによって SFQ 論理回路として体系づけられ $た^{(2)}$ 。

SFQ 回路動作の説明の前に, SFQ 回路のスイッチング素 子である Josephson 接合の構造とその電流-電圧特性を図 1 に示す。Josephson 接合は $\mathrm{nm}$ オーダーの薄い絶縁膜を超伝 導体で挟み込んだ構造をしている。この Josephson 接合に臨 界電流 $\left(\mathrm{I}_{\mathrm{C}}\right)$ よりも低い電流が流れているとき, 接合の両端 には電圧が発生しない。しかし接合に流れる電流が臨界電 流值を超えた瞬間, 接合の両端に電圧が発生する。接合を 流れている電流が臨界電流值以下になると, 有電圧状態の 接合はただちにゼロ電圧状態に戻る。Josephson 接合におい て有電圧状態とゼロ電圧状態の切り替えが瞬時に起こるこ とが, SFQ 回路の高速性の一つの要因になっている。

図 2 にSFQ 回路の構造図を示す。SFQ 回路は Josephson 接合 $(\mathrm{JJ})$ を含む超伝導リングが接続された形状をしている。 


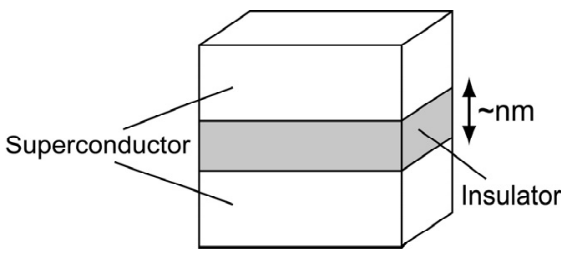

(a) Josephson junction

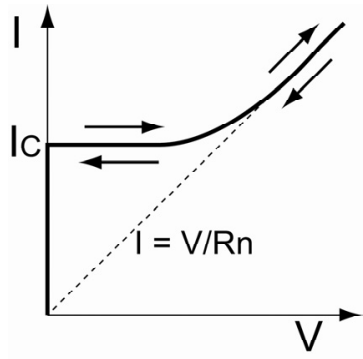

(b) Current-voltage characteristic

図 1 積層型ジョセフソン接合の構造と電流-電圧特性

Fig. 1. Structure and current-voltage characteristic of a Josephson junction.

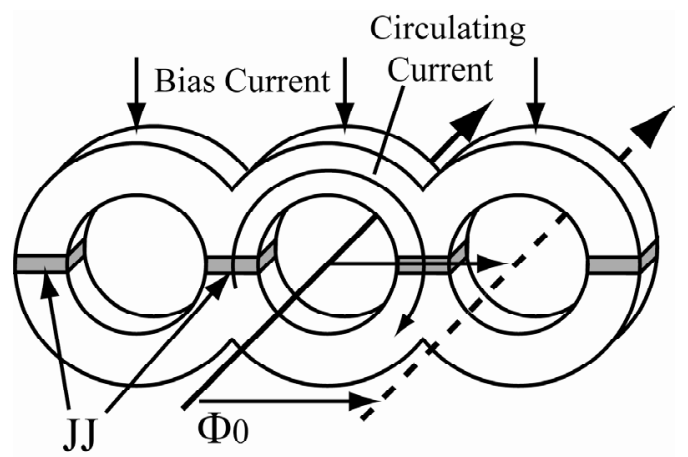

図 2 超伝導 SFQ 回路の構造

Fig. 2. Structure of an SFQ circuit. $\Phi_{0}$ denotes a flux quantum.

各接合には臨界電流值を超えない程度に, 外部からバイア ス電流が印加されている。この状態で超伝導リングに単一 の磁束量子が入力されると, 超伝導リングには磁束量子を 保持しようとして循環電流が流れる（図 2 の場合は時計回 り)。この時, 超伝導リング中の右側の Josephson 接合は, もともとバイアスされていた電流值と, 循環電流によって 流れる電流の和が臨界電流值を超え, 有電圧状態にスイッ チ寸る。このとき超伝導リング中の磁束量子は, バイアス 電流からクーロン斥力を受け, 右隣のリングに移る。磁束 量子が飛び出した超伝導リングは, 循環電流が無くなるた め, 接合を流れる電流值は臨界電流值以下になり, Josephson 接合は直ちにゼロ電圧状態に戻る。この動作が接続された 超伝導リングで次々と起こり, 磁束量子は回路中を伝搬し て行く。上の例では磁束量子の伝搬動作のみ述べたが, Josephson 接合の臨界電流值などの回路パラメータの調整に よって, 入力された磁束量子を超伝導リング中に保持する こともできる。この超伝導リング中の単一磁束量子の伝搬

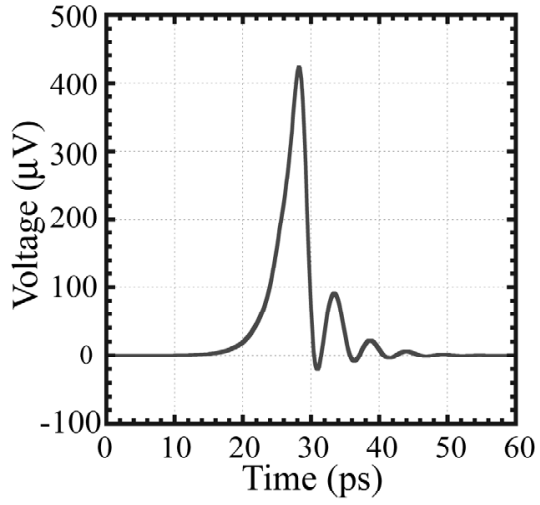

図 $3 \mathrm{SFQ}$ パルスの時間波形

Fig. 3. Waveform of an SFQ pulse.

と保持を組み合わせることによって，SFQ 回路はあらゆる 論理動作が可能である。

磁束量子回路の伝搬時には, Josephson 接合の両端に単一 の磁束量子の通過に伴う微小なパルス状の電圧が発生す る。これを $\mathrm{SFQ}$ パルスと呼ぶ。図 3 に SFQ パルスの時間波

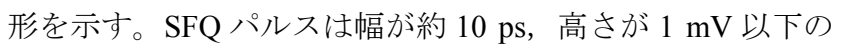
急峻な電圧パルスとなる。SFQ 回路中では, 磁束量子, あ るいは SFQ パルスが回路中を高速で飛びまわっていること になる。

$\mathrm{SFQ}$ パルスの幅が $10 \mathrm{ps}$ ということは, SFQ 回路において は 1 ビットの信号を $10 \mathrm{ps}$ 程度の時間で表現できるというこ とであり, 数十 $\mathrm{GHz}$ の高速な動作が可能であることにつな がる。また, 微小な電圧で信号が表現でき, さらに回路が 動作しないときは回路中に電圧が発生しないことから, SFQ 回路は超低消費電力動作が可能である。半導体集積回路に 比べて SFQ 回路は 3 桁以上低い消費電力で動作可能である ことが知られている。

この超伝導 SFQ 回路を用いてこれまでにさまざまな回路 の高速動作実証がされてきた。本稿で述べるマイクロプロ セッサ以外の回路応用としては, 高性能なネットワークル ータの実現を目指した SFQ ネットワークスイッチ回路の 50 $\mathrm{GHz}$ 動作 ${ }^{(4)}$ などがある。単体のフリップフロップにおいて は， $750 \mathrm{GHz}$ までの高速動作が実証されている(5)。

\section{SFQ マイクロプロセッサの開発}

我々は SFQ 回路を, 情報処理システムの中核であるマイ クロプロセッサに応用す心゙く, 研究を続けてきた。マイク ロプロセッサは最も複雑なディジタル回路であり, この動 作実証を通じて SFQ 回路設計法や, 動作実証法についての 知見が得られることも目的としている。

SFQ 回路の設計には, Josephson 接合を含む超伝導リング の接続と, 回路パラメータの調節を行えばよいが, マイク ロプロセッサのような大規模な回路においてこの作業を行 うのは現実的でない。我々は大規模 SFQ 回路を設計するた めに, セルベース設計法, SFQ セルライブラリ ${ }^{(6)}$, セルベー スディジタル設計法を開発した。セルベース設計法におい 
ては，AND や OR などの基本回路をセルとして設計してお き，それらを並べるだけで所望の機能を持つ回路を設計す る，というものである。セルベース設計法のために，300 種 類以上のセルから構成される SFQ セルライブラリを開発し た。さらにセルを並べた状態でのディジタル回路シミュレ ーションを開発し，設計時に回路の動作検証を行うことが できる。各セルはチップ作成時の回路パラメータのバラッ キに対して十分な耐性を持つように回路パラメータが最適 化されている。このセルライブラリは, 超電導工学研究所 が所有する SRL $2.5 \mathrm{kA} / \mathrm{cm}^{2} \mathrm{Nb}$ 標準プロセス ${ }^{(7)} の$ 仕様に従っ て開発された。このプロセスはジョセフソン接合以外に 3 層の $\mathrm{Nb}$ 超伝導配線層（最小線幅は $1.0 \mu \mathrm{m}$ ）を有し，回路パ ラメータのバラツキも十分小さい回路を作成することがで きる。測定では, チップを液体へリウム中に浸して Josephson 接合と配線で使用されている $\mathrm{Nb}$ を超伝導状態にし，信号を 入力しながらその出力を確認して動作検証を行う。

現行の SFQ 集積回路は集積度が半導体回路に比べて格段 に低い。このため半導体マイクロプロセッサにおける処理 のように，データの並列的な処理を行うと面積コストが大 きくなってしまう。そこで我々はデータを 1 ビットずつ直 列的に処理する方法を用いて回路を設計した。SFQ 回路の 高いスループットを利用することによって，1 ビットずつの 直列処理においても高い性能を維持することができる。

マイクロプロセッサは，算術論理演算を行う ALU (Arithmetic Logic Unit), データを保持するレジスタなどの複 数の要素回路から構成される。マイクロプロセッサの設計 においては, 最初に決めた全体の仕様に従って全ての要素 回路を設計し，ディジタルシミュレーションを行いながら 要素回路を統合する方法で全体の設計を行った。マイクロ プロセッサの機能が正しく実行されるためには，すべての 要素回路間でデータや制御信号が適切な順序, タイミング で受け渡される必要があり, マイクロプロセッサ全体の設 計には数日から数週間の時間を要する。

我々は最初にマイクロプロセッサとしての基本動作の実 証をするために，マイクロプロセッサとして必要最小限の 機能を持つ 8 ビット SFQ マイクロプロセッサの開発を行っ た。このシンプルなマイクロプロセッサを我々は CORE1 $\alpha$ と呼んでいる。最初に動作実証に成功した SFQ マイクロプ ロセッサは，CORE1 $\alpha$ version 5 である。約 5000 個のジョセ フソン接合から成るこのプロセッサは, $1.6 \mathrm{~mW}$ の消費電力 において，最大 $15.2 \mathrm{GHz}$ までのクロック周波数において動
作した ${ }^{(8)}$ 。この version 5 をさらに改良し, 機能性, 性能を 上げたものの動作実証にも成功した。CORE1 $\alpha$ ver.6 では要 素回路間の配線に, SFQ パルスの光速無損失伝送が可能な 超伝導受動線路（PTL）を用いた ${ }^{(9)}$ 。さらにCORE1 $\alpha$ ver.10 では 4 バイトの SFQ シフトレジスタ型メモリを搭載してい る。

CORE1风マイクロプロセッサは, 基本的な動作を実証する ことを目的としたプロセッサであり，その最大性能は 240 MOPS (Million Operations Per Second: 1 秒間に 2.4 億回の動 作が可能）であった。この值は現在の半導体マイクロプロ セッサに比べて 1 桁以上低い。我々は半導体マイクロプロ セッサに劣らない性能を持つプロセッサの実現を目指し, 新しいSFQ マイクロプロセッサの開発を行った。このプロ セッサをCORE1ßと呼んでいる。

CORE1ßにおいて性能を上げるために取り入れた手法は 主にふたつある。ひとつ目は, 複数の ALUを接続した構成 を用いたことである。マイクロプロセッサにおける算術論 理演算は，レジスタから読みだされたデータをALUに入力 し，演算結果をレジスタに書き戻すことで実行される。こ のときに複数の ALU を接続することによって，レジスタか ら読みだされたデータが書き戻されるまでに, 複数の算術 論理演算を行うことができる。

もう一つの手法は，パイプライン処理である。パイプラ

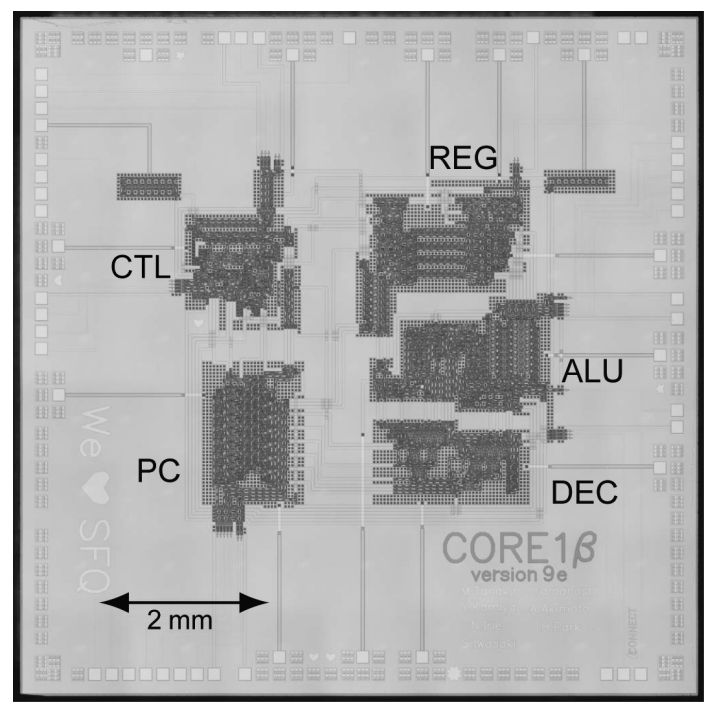

図 4 CORE1 $\beta$ ver.9 マイクロプロセッサ

Fig. 4. CORE1 $1 \beta$ ver.9 microprocessor.

表 1 SFQ マイクロプロセッサ

Table 1. SFQ microprocessors.

\begin{tabular}{|c|c|c|c|c|l|}
\hline & $\begin{array}{c}\text { Total } \\
\text { Junctions }\end{array}$ & $\begin{array}{c}\text { Clock Frequency } \\
(\mathrm{GHz})\end{array}$ & $\begin{array}{c}\text { Power } \\
\text { Consumption } \\
(\mathrm{mW})\end{array}$ & $\begin{array}{c}\text { Performance } \\
(\mathrm{MOPS})\end{array}$ & \multicolumn{1}{|c|}{ Features } \\
\hline CORE1 $\alpha$ ver.5 $5^{(8)}$ & 4999 & 15.2 & 1.6 & 167 & Simple prototype microprocessor \\
\hline CORE1 $\alpha$ ver. $6^{(9)}$ & 6319 & 18.0 & 2.1 & 240 & PTL wiring between circuit blocks \\
\hline CORE1 $\alpha$ ver.9 & 7220 & 21.0 & 2.3 & 200 & Implementation of a 4-Byte SFQ memory \\
\hline CORE1 $\beta$ ver. $9^{(11)}$ & 10995 & 18.0 & 3.4 & 1400 & 2 cascaded ALUs, 4-stage pipelining \\
\hline
\end{tabular}


イン処理は，ある命令が完了する前に次の命令の処理を始 めることによって，複数の命令を同時に実行することがで きる手法である。このパイプラインの実現のためには複数 の命令を巧妙に制御できる高機能な制御回路が必要になる が，SFQ 回路に適した新しい制御回路 ${ }^{(10)}$ を実現することに より, SFQ マイクロプロセッサへのパイプライン処理の実 装に成功した。

動作実証に成功した CORE1 $\beta$ ver.9 マイクロプロセッサで は，2 個の ALU を搭載し，4 段パイプライン処理を（同時 に 4 つの命令を実行) 行うことによって最大性能 1400MOPS と CORE1 $\alpha$ に比べて高い性能を実現した ${ }^{(1)}$ 。CORE1 $\beta$ ver.9 マイクロプロセッサのチップ写真を図 4 に示す。

これまでに動作実証に成功した SFQ マイクロプロセッサ の性能や簡単な特徵を表 1 に示す。

\section{4. おわりに}

我々の開発している単一磁束量子回路を用いたマイクロ プロセッサについて述べた。単一磁束量子回路の高速性や 特色を生かしたマイクロプロセッサの構成の検討を行い，2 個の ALU， 4 段パイプライン処理を実装した 8 ビット SFQ マイクロプロセッサの高速動作実証に成功した。

最小線幅が $1 \mu \mathrm{m}$ と半導体回路に比べてはるかに貧弱なプ ロセスにおいて, $20 \mathrm{GHz}$ を超える周波数で SFQ マイクロプ ロセッサの動作を実証することができた。SFQ 回路におい ても回路の微細化によって動作速度は上がることから，微 細加工技術の進歩によって回路の速度，集積度を上げてい くことができる。これまでに SFQ 回路の基本的な設計技術, 作成技術は確立したと言える。今後は回路の微細化と同時 に，SFQ 回路の特徴である高スループット性，低消費電力 性を最大限利用できる応用，さらには SFQ 回路でしか実現 不可能な応用を探求していく必要がある。

(平成 20 年 2 月 21 日受付)

\section{文献}

(1) http://www.itrs.net/Links/2006Update/2006UpdateFinal.htm

(2) K. K. Likharev and V. K. Semenov : "RSFQ Logic/Memory Family: A New Josephson-Junction Technology for Sub-Terahertz-Clock-Frequency Digital Systems", IEEE Trans. Appl. Supercond., Vol.1, pp.3-28 (1991)

( 3 ) K. Nakajima, G. Oya, and Y. Sawada : "Fluxoid motion in phase mode Josephson switching system", IEEE Trans. Magnetics, Vol.19, pp.1201-1204 (1983)

(4) Y. Kameda, S. Yorozu, Y. Hashimoto, H. Terai, A. Fujimaki, and N. Yoshikawa : "High-speed demonstration of single-flux-quantum cross-bar switch up to $50 \mathrm{GHz}$ ", IEEE Trans. Appl. Supercond., Vol.15, pp.6-10 (2005)

(5) W. Chen, A. V. Rylyakov, V. Patel, J. E. Lukens, and K. K. Likharev "Superconductor digital frequency divider operating up to $750 \mathrm{GHz}$ ", Appl. Phys. Lett., Vol.73, pp.2817-2819 (1998)

(6) S. Yorozu, Y. Kameda, H. Terai, A. Fujimaki, T. Yamada, and S. Tahara : "A single flux quantum standard logic cell library", Physica $C$, Vol.378-381, pp.1471-1474 (2002)

( 7 ) S. Nagasawa, Y. Hashimoto, H. Numata, and S. Tahara : "A 380ps, 9.5 $\mathrm{mW}$ Josephson 4-kbit RAM operated at a high bit yield", IEEE Trans. Appl. Supercond., Vol.5, pp.2447-2452 (1995)

(8) M. Tanaka, F. Matsuzaki, T. Kondo, N. Nakajima, Y. Yamanashi, A. Fujimaki, H. Hayakawa, N. Yoshikawa, H. Terai, and S. Yorozu : “A single-flux-quantum logic prototype microprocessor”, Tech. Dig. IEEE Int. Solid-State Circuit Conf., San Francisco, CA (2004)

(9) M. Tanaka, T. Kondo, N. Nakajima, T. Kawamoto, Y. Yamanashi, Y. Kamiya, A. Akimoto, A. Fujimaki, H. Hayakawa, N. Yoshikawa, H. Terai, Y. Hashimoto, and S. Yorozu : "Demonstration of a singleflux-quantum microprocessor using passive transmission lines", IEEE Trans. Appl. Supercond., Vol.15, pp.400-404 (2005)

(10) Y. Yamanashi, A. Akimoto, N. Yoshikawa, M. Tanaka, T. Kawamoto, Y. Kamiya, and A. Fujimaki : "A New Design Approach for Control Circuits of a Pipelined Single-Flux-Quantum Microprocessor", Supercond. Sci. Technol., Vol.19, pp.S340-S343 (2006)

(11) Y. Yamanashi, M. Tanaka, A. Akimoto, H. Park, Y. Kamiya, N. Irie, N. Yoshikawa, A. Fujimaki, H. Terai, and Y. Hashimoto : "Design and Implementation of a Pipelined Bit-Serial SFQ Microprocessor, CORE1 $\beta$ ", IEEE Trans. Appl. Supercond., Vol.17, pp.474-477 (2007)

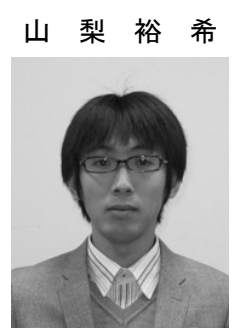

会会員。

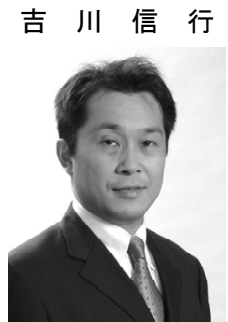

（正員） 1961 年 12 月 27 日生。1989年 3 月横 浜国立大学大学院工学研究科博士後期課程電 子情報工学専攻修了。同年 4 月同大学工学部電 子情報工学科助手。1993 年同大工学部電子情報 工学科助教授。1995 年より 1 年間カリフォルニ ア大学バークレー校客員研究員。現在, 横国大 大学院工学研究院教授。主として超伝導エレク トロニクス, 単電子デバイス, 量子効果デバイ ス, 低温デバイス, 単一磁束量子回路, 集積回路設計に関する研究 に従事。工学博士。2005 年未踏科学技術協会超伝導科学技術賞。応 用物理学会, 電子情報通信学会, IEEE 会員。

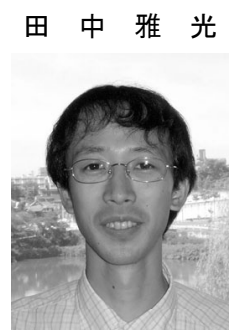

(非正員) 1979 年 8 月 29 日生。2003 年 3 月名 古屋大学大学院工学研究科電子工学専攻博士 前期課程修了, 2006 年 3 月電子情報学専攻博士 後期課程修了。2005 2007 年日本学術振興会特 別研究員。現在, 同大学院情報科学研究科研究 員として単一磁束量子集積回路に関する研究 に従事。博士 (工学)。応用物理学会, 電子情 報通信学会, IEEE 会員。

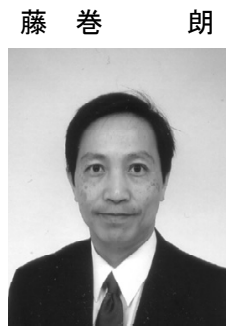

(非正員) 1959 年 8 月 24 日生。1987 年 3 月東 北大学工学研究科博士課程修了。1987 年カリフ オルニア大学バークレー校客員研究員。1988 年より名古屋大学工学研究科助手。現在, 名古 屋大学工学研究科教授。低温および高温超伝導 体を用いた単一磁束量子回路の忘用に関する 研究に従事。工学博士。応用物理学会, 電子情 報通信学会会員。 